\title{
Vibration Spectroscopy Potential for Beef and Pork Determination
}

\author{
Muhammad Yudha Syahputra ${ }^{1}$, Alvin Juniawan ${ }^{2}$, Suprapto ${ }^{1}$, and Fredy Kurniawan ${ }^{1}$ \\ ${ }^{1}$ Department of Chemistry, Institut Teknologi Sepuluh Nopember, Surabaya \\ ${ }^{2}$ Department of Biology, Islamic University Al-Azhar, Mataram \\ e-mail: fredy@chem.its.ac.id
}

\begin{abstract}
Meat is one of the most foodstuff consumed. The increasing consumption of meat had led some traders to falsify the identity of meat for gaining profit. The meat adulteration case that often occurs is substituting the beef with pork. This adulteration case is very detrimental to consumers, therefore a method to identify the type of meat sold is very necessary. The vibration spectroscopy method, Fourier Transform Infra Red (FTIR), had been developed to analyze the type of beef and pork. The FTIR measurement was carried out with cut raw meat samples without further preparation. The Data obtained from the measurement are infra-red spectrum from beef and pork from $4000-500 \mathrm{~cm}^{-1}$ wavenumber and then the data was analyzed with Principle Component Analysis (PCA) statiscticall method. Projection result with PCA obtained data reduction that can represent all data generated from measurements shown through the Principle Component 1 and Principle Component 2 regions. Based on those projection, beef and pork profile area can be classified properly.
\end{abstract}

Keywords-Halal, Fourier Transform Infra Red, Raw Meat, Principle Component Analysis.

\section{INTRODUCTION}

$\mathrm{M}$ EAT is one of the most consumed foodstuffs, at 2019 meat consumption in indonesia had reached 2.6 $\mathrm{kg} /$ capita [1]. Increased consumption results in many cases of meat counterfeiting. Common cases of meat counterfeiting that often occur is replacing and mixing beef with pork for economic reasons. This happens because of the high differences in price of beef and pork [2]. The case of meat counterfeiting is a serious problem for Muslims because pigs and their derivatives are haram. Therefore, several analyticals methods had been developed to identify pork.

Pork detection can be done by several methods and instruments such as Polymerize Chain Reaction (PCR) method, Liquid Chromatography paired with mass spectroscopy and Fourier Transform Infra Red (FTIR) spectroscophy. The PCR method is able to analyze meat origins at the DNA level by replication of a single into millions of DNA through repeated heating and cooling cycles of a mixture of DNA templates, DNA polymerases, primers and nucleotides. In measurements using PCR, the sample needs several stages of preparation such as denaturation, primer anealing and DNA extension to obtain sample DNA [3]. Based on research conducted by Cheng et al in 2016, PCR was able to differentiate processed meat origins from pigs, cows, goats, chickens and rabbits based on differences in DNA constituents [4]. Identification of meat types can also be done by chromatography method paired with a massspectroscopy instrument. This method analyzes samples by separating the compounds in the sample based on chemical properties through liquid chromatography to be further detected by mass spectroscopy [5]. Grundy et al in 2008 succeeded in identifying the origin of meat from blood plasma samples found in meat using the LC-MS method [6]. Another method that can be used to identify the type of meat is FTIR based on the functional group of compounds contained in meat. This method is able to analyze the level of pig content in the fingerprint area. pig hair and cow hair can be analyze using FTIR in the range of 1215-2007 $\mathrm{cm}^{-1}$ and 3467-3989 $\mathrm{cm}^{-1}$ [7].

In the meat identification for the halal verification purpose on food ingredient, fast measurement and simple sample preparation is needed to get faster results [8]. FTIR spectrophotometry is one method that is widely exploited for meat analysis because of the speed to do fast screening due to the properties of fingerprint region contained in FTIR spectra, where each meat will provide a different spectra profile [9]. Till now, measurements using FTIR spectroscopic methods require extraction to obtain fatty acid or protein compound in meat for further analysis. In this study, measurements by the FTIR spectroscopic method will be carried out using raw meat samples without further preparation. FTIR spectra data obtained from measurements will be processed using the Principal Component Analysis (PCA) chemometric method. It aims to extract useful information from FTIR spectra data representing each functional group of compound components in meat.

\section{MATERIALS AND METHOD}

\section{A. Materials}

Materials used in this research are 5 beef and 5 pork. While tool used in this reseach is FTIR Spectroscopy(Agilent-Cary 630 Portable FTIR) which is connected to Microlab Expert software to procces the measured data.

\section{B. Method}

Fresh meat were cutted into small and thin so it can fit the sample chamber of the instrument, than the raw meat was measured by FTIR Spectroscopy. FTIR Spectra obtained from the measurement are then processed using Origin Lab 8.0 for classification using the PCA method.

\section{RESULT AND DISCUSSION}

Meat consist of $71-75 \%$ waters, $21 \%$ Nitrogen containing compoung including protein, $2,5-5 \%$ fat, $1 \%$ vitamins and $1 \%$ minerals [10-11]. Thus, the measured FTIR spectra will 
The $6^{\text {th }}$ International Seminar on Science and Technology (ISST) 2020

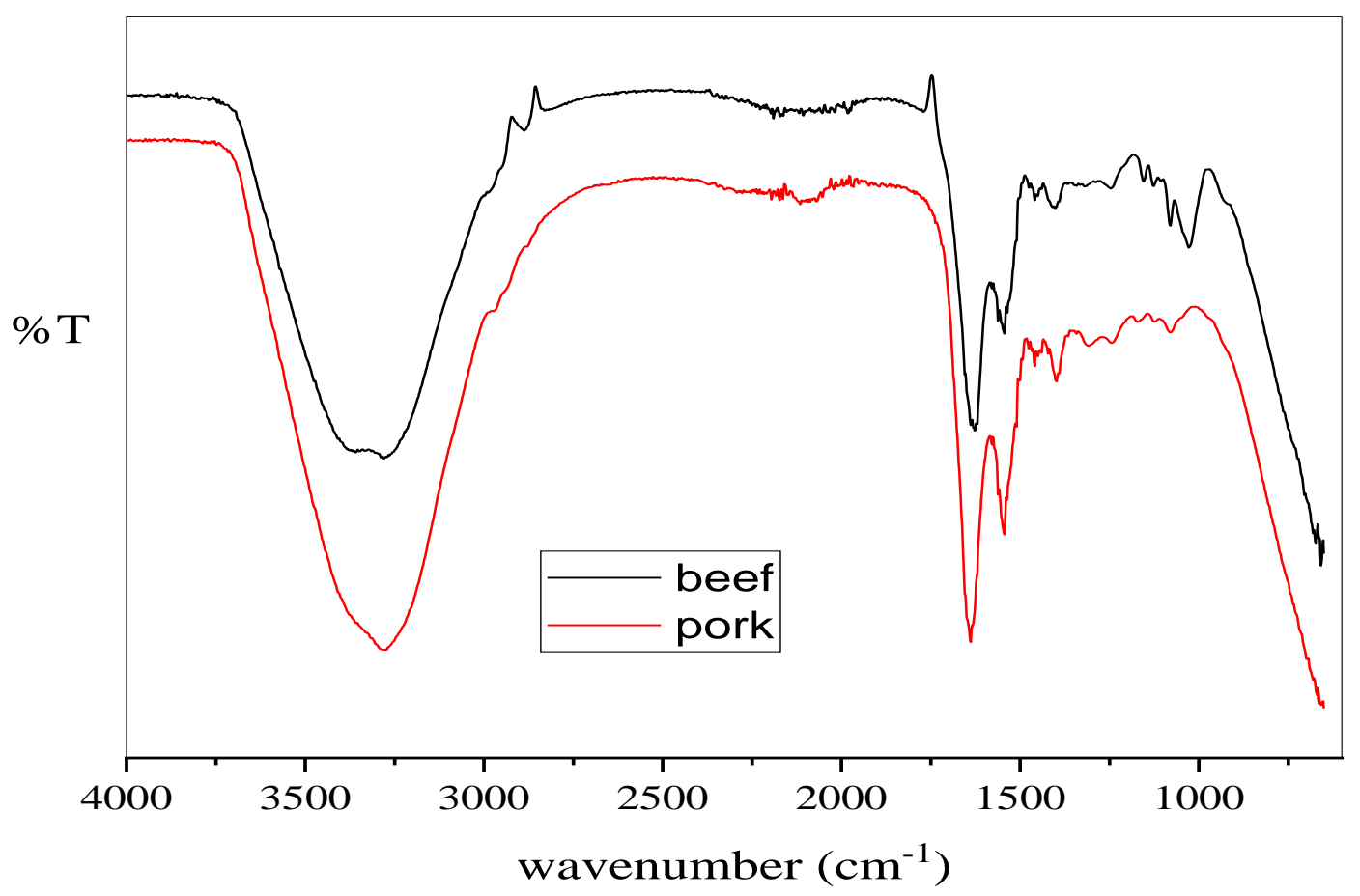

Figure 1. FTIR spectra of beef (black) dan pork (red).

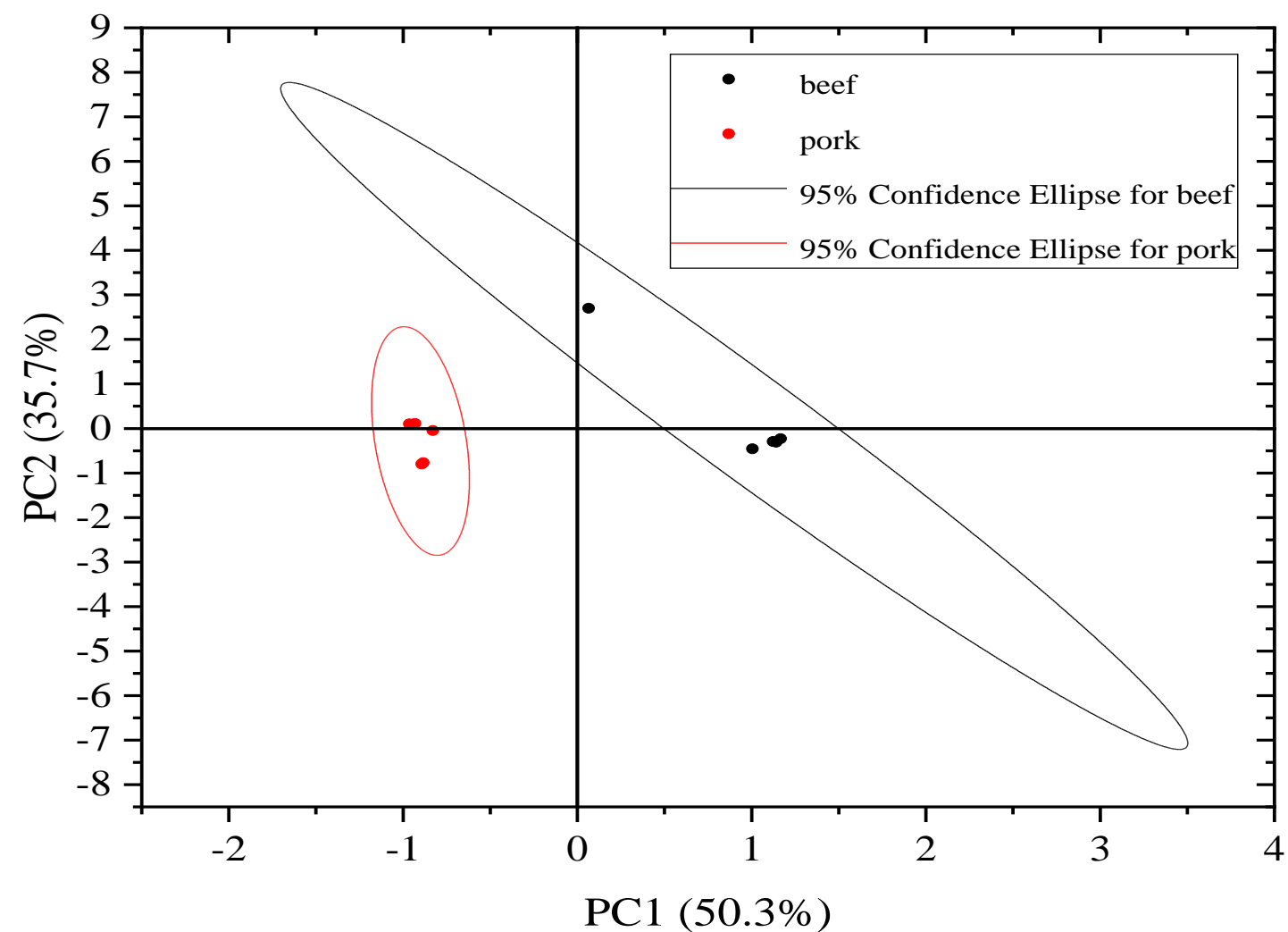

Figure 2. The score plot of first principal component and second principal component of beef (black) and pork (red).

represent every functional group of the meat constituent compound.

Figure 1 shows FTIR spectra of raw beef (black) and pork (red) obtained from measurement using Agilent-Cary 630 portable FTIR spectroscopy. The obtained specyta show peaks and valleys representing each functional group from the molecule as a result of infrared absorption at 4000-400 $\mathrm{cm}^{-1}$ wavenumber. FTIR spectra shows a view functional group profile at each specific wavenumber, i.e. at 3600-2700 $\mathrm{cm}^{-1}$ region wavenumber is attributed to $\mathrm{O}-\mathrm{H}$ bending from water and carbohydrate molecules and also $\mathrm{N}-\mathrm{H}$ amide stretching functional group originate to protein molecule 
The $6^{\text {th }}$ International Seminar on Science and Technology (ISST) 2020

July $25^{\text {th }} 2020$, Institut Teknologi Sepuluh Nopember, Surabaya, Indonesia

content, peak shows at wavenumber between $3250-3000 \mathrm{~cm}^{-}$ ${ }^{1}$ region originate to $\mathrm{C}-\mathrm{H}$ sp3 functional group, at 1600-1700 $\mathrm{cm}^{-1}$ region $\mathrm{C}=\mathrm{O}$ functional group from fatty acid and protein molecule detected, the other peaks showed at $1500 \mathrm{~cm}^{-1}$ correspond to $\mathrm{N}-\mathrm{H}$ bending functional group from protein and at $1500 \mathrm{~cm}^{-1}$ wavenumber region the $\mathrm{C}-\mathrm{O}$ functional group from fats and carbohydrate is observed [12-13]. FTIR spectra from prok and beef at functional group region are difficult to differentiate since providing the same profile. The feature of fingerprint region in FTIR spectra however showing a differences in wavenumber for both measured FTIR spectra. Furtermore raw data obtained from FTIR measurement was classified using PCA method.

The PCA plot score from beef and pork demonstrated in Figure 2, representeing the sample projection explained by first principal componen (PC1) and second principal component (PC2). The PCA ploting result in Figure 2 shows well classified beef and pork cluster, from the obtained PCA plot beef and pork can be distinguish properly. Every measured pork sample will be classified at red cluster area, while measured beef sample will be classified at black cluster area.

\section{CONCLUSION AND RECOMMENDATION}

It can be concluded that the FTIR spectroscopy method combined with PCA chemometric method can be succesfully used to identify the meat sampel origin. The PCA method helps in the classification of types of meat samples by clustering for each beef and pork. The developed method perform a fast measurement time and requires a simple preparation. Further measurements can be made for other types of animal meat, because there are some animals that also appointed as haram meat.

\section{REFERENCES}

[1] N. Rusono, 'Peningkatan Produksi Daging Sapi untuk Mewujudkan Kedaulatan Pangan Hewani', in Prosiding Seminar Nasional Teknologi Peternakan dan Veteriner, 2020, pp. 12-22.

[2] Y. Erwanto, S. Sugiyono, A. Rohman, M. Z. Abidin, and D. Ariyani, 'Identifikasi Daging Babi Menggunakan Metode PCR-RFLP Gen Cytochrome b dan PCR Primer Spesifik Gen Amelogenin', agriTECH, vol. 32, no. 4, 2012.

[3] M. Jalali, J. Zaborowska, and M. Jalali, 'Chapter 1 - The Polymerase Chain Reaction: PCR, qPCR, and RT-PCR', in Basic Science Methods for Clinical Researchers, M. Jalali, F. Y. L. Saldanha, and M. Jalali, Eds. Boston: Academic Press, 2017, pp. 1-18.

[4] J.-H. Cheng, H.-T. Chou, M.-S. Lee, and S.-C. Sheu, 'Development of qualitative and quantitative PCR analysis for meat adulteration from RNA samples', Food Chemistry, vol. 192, pp. 336-342, Feb. 2016.

[5] O. Abbas et al., 'Analytical methods used for the authentication of food of animal origin', Food Chemistry, vol. 246, pp. 6-17, Apr. 2018.

[6] H. H. Grundy, P. Reece, M. D. Sykes, J. A. Clough, N. Audsley, and R. Stones, 'Method to screen for the addition of porcine blood-based binding products to foods using liquid chromatography/triple quadrupole mass spectrometry', Rapid Communications in Mass Spectrometry, vol. 22, no. 12, pp. 2006-2008, 2008.

[7] H. Rahmania and A. Rohman, 'The employment of FTIR spectroscopy in combination with chemometrics for analysis of rat meat in meatball formulation', Meat Science, vol. 100, pp. 301-305, 2015.

[8] S. Rahmati, N. M. Julkapli, W. A. Yehye, and W. J. Basirun, 'Identification of meat origin in food products-A review', Food Control, vol. 68, pp. 379-390, Oct. 2016, doi: 10.1016/j.foodcont.2016.04.013.

[9] O. Papadopoulou, E. Z. Panagou, C. C. Tassou, and G.-J. E. Nychas, 'Contribution of Fourier transform infrared (FTIR) spectroscopy data on the quantitative determination of minced pork meat spoilage', Food Research International, vol. 44, no. 10, pp. 3264-3271, Dec. 2011.

[10] Á. Cobos and O. Díaz, 'Chemical Composition of Meat and Meat Products', in Handbook of Food Chemistry, P. C. K. Cheung, Ed. Berlin, Heidelberg: Springer, 2015, pp. 1-32.

[11] E. Pogorzelska-Nowicka, A. G. Atanasov, J. Horbańczuk, and A Wierzbicka, 'Bioactive Compounds in Functional Meat Products', Molecules, vol. 23, no. 2, Jan. 2018, doi: 10.3390/molecules23020307.

[12] M. Lucarini, A. Durazzo, J. Sánchez del Pulgar, P. Gabrielli, and G. Lombardi-Boccia, 'Determination of fatty acid content in meat and meat products: The FTIR-ATR approach', Food Chemistry, vol. 267, pp. 223-230, Nov. 2018, doi: 10.1016/j.foodchem.2017.11.042.

[13] N. Perisic, N. K. Afseth, R. Ofstad, and A. Kohler, 'Monitoring Protein Structural Changes and Hydration in Bovine Meat Tissue Due to Salt Substitutes by Fourier Transform Infrared (FTIR) Microspectroscopy', J. Agric. Food Chem., vol. 59, no. 18, pp. 10052-10061, Sep. 2011. 